\title{
INCREASED TRANSPORT OF 44,000- to 49,000-DALTON ACIDIC PROTEINS DURING REGENERATION OF THE GOLDFISH OPTIC NERVE: A TWO-DIMENSIONAL GEL ANALYSIS ${ }^{1}$
}

\author{
LARRY I. BENOWITZ ${ }^{2}$ AND ELLEN R. LEWIS
}

Department of Psychiatry, Harvard Medical School, Mailman Research Center, McLean Hospital, Belmont, Massachusetts 02178

Received January 28, 1983; Revised May 3, 1983; Accepted May 5, 1983

\begin{abstract}
Protcins synthesized in goldfish retinal ganglion cells and rapidly transported to the terminals of regenerating optic nerves were analyzed by two-dimensional (2-D) gel electrophoresis. Among the rapidly transported components, the most dramatic change observed during regeneration was for a family of polypeptides having molecular weights between 44,000 and 49,000 (44-49K) and isoelectric points of 4.6 to 4.9 . Studies using $\left[{ }^{35} \mathrm{~S}\right]$ methionine as a metabolic precursor in the eye showed that these proteins are present in both membranous and soluble fractions of the optic tectum, particularly during early stages of regeneration. Contralateral visual pathways, left intact to serve as controls, showed only very low levels of the proteins. These labeling changes were quantified in doubleisotope studies, in which proteins from intact and regenerating sides were differentially labeled with $\left[{ }^{3} \mathrm{H}\right]$ proline and $\left[{ }^{14} \mathrm{C}\right]$ proline, comigrated on 2-D gels, and then counted for ${ }^{3} \mathrm{H} /{ }^{14} \mathrm{C}$ ratios. The labeling change for the $44-49 \mathrm{~K}$ acidic proteins relative to the intact state was found to be over 100 fold in some day 19 regeneration samples and about 30-fold on day 40 . Silver-stained gels of a tectal membrane fraction also revealed increased levels of the $44-49 \mathrm{~K}$ acidic proteins during regeneration, indicating that the observed synthetic changes are accompanied by a net accumulation of the proteins.
\end{abstract}

The regeneration of the optic nerve in lower vertebrates has served as a model system for numerous studies on the physiological and molecular events that underlie the formation of brain circuitry. In goldfish, the optic nerve regenerates within 1 to 2 months after being crushed, to re-establish the pre-existing pattern of retinotopic projections and restore visually guided behaviors (Sperry, 1948; Attardi and Sperry, 1963; Jacobson and Gaze, 1965). During this process both quantitative and qualitative changes occur in the complement of proteins that are transported intra-axonally (see review, Grafstein and Forman, 1980). Of particular interest in several recent studies have been the proteins in the rapid phase of axonal transport ( 40 to $50 \mathrm{~mm} /$ day at $21^{\circ} \mathrm{C}$; Grafstein et al., 1972), since many of these are incorporated into developing nerve terminal membranes and may therefore play a role in such phenomena as axon elongation, growth cone motility, target recognition, and synaptogenesis (Bennett et al., 1973; Droz et al., 1975; Lorenz and

\footnotetext{
${ }^{1}$ We wish to thank Dr. Paola Strocchi for instuction in two-dimensional gel electrophoresis, Dr. Jeffrey Gilbert for comments on the work, Martha Shea for preparing the manuscript, and Wolfgang Busse for photography. Supported by National Institute of Neurological and Communicative Disorders and Stroke Grant RO1 NS16943.

${ }^{2}$ To whom correspondence should be addressed.
}

Willard, 1978). Within the first few weeks of regeneration, the amount of protein that is rapidly transported down the optic nerve increases 4- to 10-fold (Grafstein and Murray, 1969; Heacock and Agranoff, 1982; McQuarrie and Grafstein, 1982). Accompanying this overall change is a radical shift in the labeling spectrum of individual molecular species (Benowitz et al., 1981). In studies using double labeling and one-dimensional (1-D) protein separation, the most prominent labeling increases observed during regeneration were for proteins with apparent $M_{\mathrm{r}}$ of $210,000,44,000$ and $24,000(210 \mathrm{~K}$ $44 \mathrm{~K}$, and $24 \mathrm{~K}$ ) up to about day 30 after surgery, and at later times for species between 110 and 140K (Benowitz et al., 1981). However, because of the limited resolution of 1-D separation, the actual magnitude of the labeling changes could not be determined, nor could the proteins of interest be related to identified molecular species. That study also did not examine which proteins become associated with the nerve terminal membranes and did not differentiate between increased turnover and net accumulation. Increased labeling of a $45 \mathrm{~K}$ species during regeneration of the goldfish optic nerve has recently been confirmed in another study using 1-D gel analysis (Heacock and Agranoff, 1982), and in the regenerating toad visual pathway, two-dimensional (2-D) gel studies reveal labeling increases for rapidly transported proteins at 
$43 \mathrm{~K}$, as well as at $24 \mathrm{~K}$ and $50 \mathrm{~K}$ (Skene and Willard, 1981a). Changes for proteins conveyed in other phases of axonal transport also occur during optic nerve regeneration in the goldfish (Heacock and Agranoff, 1982; Giulian et al., 1980; Quitschke et al., 1980).

In the present study the changes in rapidly transported proteins associated with optic nerve regeneration have been examined in greater detail using 2 -D gel electrophoresis, subcellular fractionation, single and double isotope labeling, and silver staining. By these improvements in resolution, the most prominent change occurring during regeneration appears to involve a group of at least three highly acidic proteins with apparent $M_{r}$ between 44,000 and 49,000 . These proteins are present in both the soluble and nerve terminal membrane fractions and increase over 100 -fold in some of our regenerating material.

\section{Materials and Methods}

Surgery and labeling. Common goldfish (3 to 4 inches length; Ozark Fisheries, St. Louis, MO) were anesthetized in Finquel (tricaine methanesulfonate; The Upjohn Co., Kalamazoo, MI) and placed in a holder with water circulating through the gills. The right optic nerve was exposed and crushed 1 to $2 \mathrm{~mm}$ behind the eye using jewelers' forceps. The left nerve remained intact to serve as a control for the normal labeling pattern. In most experiments goldfish were labeled either 19 or 40 days after surgery, time points at which distinctive labeling patterns have previously been found in the rapid phase of transport (Benowitz et al., 1981).

In experiments that compared samples to be separated on different gels, protiens were labeled with $\left.{ }^{35} \mathrm{~S}\right] \mathrm{methi}$ onine ( 1000 to $1200 \mathrm{Ci} / \mathrm{mmol}$, NEG-009T; New England Nuclear Corp., Boston, MA), which had been dried down and redissolved in $0.01 \mathrm{M}$ phosphate-buffered saline (PBS), pH 7.4. Intraocular injections of $200 \mu \mathrm{Ci}$ in $4 \mu \mathrm{l}$ of PBS were done under microscopic guidance using a 10- $\mu$ l Hamilton syringe. In double-labeling studies, proteins synthesized on the intact and regenerating sides were differentially labeled with either $100 \mu \mathrm{Ci}$ of $\left[{ }^{3} \mathrm{H}\right]$ proline (NET- $285,3.5 \mathrm{Ci} / \mathrm{mmol}$ ) or $8 \mu \mathrm{Ci}$ of $\left[{ }^{14} \mathrm{C}\right]$ proline (NEC-285, $290 \mathrm{mCi} / \mathrm{mmol}$; both from New England Nuclear), for subsequent co-separation on 2-D gels. All injections were in $4 \mu \mathrm{l}$ of PBS and were equimolar in proline. In some experiments the regenerating side was labeled with $\left[{ }^{14} \mathrm{C}\right]$ proline and the control with $\left[{ }^{3} \mathrm{H}\right]$ proline, whereas in others the isotopes were reversed.

Tissue preparation. Goldfish were allowed to survive 5 to $24 \mathrm{hr}$ after labeling, depending upon the group of proteins to be analyzed. Following anesthetization by cooling to 0 to $4^{\circ} \mathrm{C}$, optic nerves and tecta were removed under microscopic guidance. Nerve segments were retained from $2 \mathrm{~mm}$ behind the eye up to the chiasm; tecta were dissected free of other midbrain structures. Dissected tissues were placed in a homogenization buffer containing $300 \mathrm{mM}$ sucrose, $50 \mathrm{mM}$ Tris- $\mathrm{HCl}, \mathrm{pH} 7.4,3$ mM diothiothreitol, $10 \mathrm{~nm}$ DNase, $10 \mathrm{~nm}$ RNase, and 5 $\mathrm{mM}$ of nonradioactive amino acid (methionine or proline, to displace noncovalently bound label), at 0 to $4^{\circ} \mathrm{C}$. In most experiments samples were combined from six to eight animals.

Tissue was homogenized in a glass-Teflon system (0.25-mm gap, 10 strokes, $5000 \mathrm{rpm}$ ). For optic nerve samples, material was centrifuged at $17,000 \times g$ for 30 $\min \left(0\right.$ to $\left.4^{\circ} \mathrm{C}\right)$, the total particulate fraction was saved, and the supernatant was centrifuged again at $100,000 \times$ $g$ for $90 \mathrm{~min}$. The soluble fraction was dialyzed three times against $400 \mathrm{vol}$ of $50 \mathrm{~mm}$ ammonium acetate $(8$ to $15 \mathrm{hr}$ each), lyophilized, and stored at $-20^{\circ} \mathrm{C}$. Particulate material from the nerve was not further purified since preliminary experiments had shown fractionation to significantly decrease the yield of labeled proteins without increasing specific activity. For tectal samples, homogenates were centrifuged first at $1,000 \times g$ for $10 \mathrm{~min}$, the $\mathrm{P}_{1}$ fraction was discarded, and the supernatant was centrifuged again at $17,000 \times g$ for $30 \mathrm{~min}\left(0\right.$ to $\left.4^{\circ} \mathrm{C}\right)$. The $\mathrm{P}_{2}$ pellet was resuspended in buffer, aliquots were taken for protein determination and counting, and the remainder was centrifuged down at $17,000 \times g$ for $30 \mathrm{~min}$ and stored at $-70^{\circ} \mathrm{C}$. The supernatant was centrifuged at $100,000 \times g$ for $90 \mathrm{~min}$, dialyzed, and lyophilized. In some cases the $\mathrm{P}_{2}$ fraction was further processed to give a broad density plasma membrane fraction (Whittaker and Greengard, 1971). For this, the $\mathrm{P}_{2}$ fraction was lysed in $1 \mathrm{ml}$ of $10 \mathrm{~mm}$ Tris- $\mathrm{HCl}, \mathrm{pH} \mathrm{7.4}$, triturated once and then again at the end of a 1-hr period, layered on a discontinuous $0.6 \mathrm{M} / 1 \mathrm{M}$ sucrose density gradient, and centrifuged at $53,000 \times \mathrm{g}$ for $2 \mathrm{hr}$ using a Beckman SW27 rotor. Material from the $0.6 / 1.0 \mathrm{M}$ sucrose interface was diluted 10 -fold in $10 \mathrm{~mm}$ Tris- $\mathrm{HCl}(\mathrm{pH} 7.4)$ and centrifuged at $17,000 \times \mathrm{g}$ for $30 \mathrm{~min}$ (all operations at 0 to $4^{\circ} \mathrm{C}$ ), and the pellet was stored at $-70^{\circ} \mathrm{C}$.

Gel electrophoresis. Proteins were separated first by isoelectric focusing, then by molecular weights, using O'Farrell's (1975) procedure as modified by Strocchi et al. (1981). Samples were thawed and solubilized with mechanical disruption in $200 \mu \mathrm{l}$ of a lysis buffer containing $6 \%$ ampholines $(2: 2: 1, \mathrm{pH} 3.5$ to $5, \mathrm{pH} 5$ to $7, \mathrm{pH} 3.5$ to 10 ; LKB Instruments, Inc., Gaithersburg, MD), $9.5 \mathrm{M}$ urea, 2\% NP-40 (Nonidet P-40, Particle Data Laboratories, Inc., Elmhurst, IL), and 5\% $\beta$-mercaptoethanol, 25 to $30^{\circ} \mathrm{C}$. These were centrifuged at $100,000 \times g$ for 1 $\mathrm{hr}$ at $25^{\circ} \mathrm{C}$, and insoluble material was discarded before being run on gels. Isoelectric focusing (IEF) gels contained $6 \%$ ampholines in the same ratio as given above. Samples were run for $16 \mathrm{hr}$ at $300 \mathrm{~V}$, then for $2 \mathrm{hr}$ at 400 $\mathrm{V}$, using the procedures of O'Farrell (1975) otherwise unchanged. At the end of the run, gels were immediately frozen to $-70^{\circ} \mathrm{C}$ in $5 \mathrm{ml}$ of equilibration buffer (O'Farrell, 1975).

For the second dimension of protein separation, 5 to $15 \%$ linear gradient SDS-polyacrylamide gels were cast to a height of $25 \mathrm{~cm}(1.5 \mathrm{~mm}$ thickness $)$ in a Hoefer SE620 apparatus. The stacking gel contained $3 \%$ acrylamide. The first-dimensional IEF gel was allowed to thaw and equilibrate for 15 to $30 \mathrm{~min}$ before being placed in the upper buffer chamber. In some gels, molecular weight standards $(200,116,92.5,66,45,31,21$, and $14.3 \mathrm{~K}$; BioRad) were run along side the IEF gel. Electrophoresis was carried out at 15 to $20 \mathrm{~mA} /$ gel until the dye front was $8 \mathrm{~cm}$ from the bottom. All other procedures followed O'Farrell's modification (1975) of the Laemmli (1970) method. Gels were stained with Coomassie brilliant blue (Schwarz-Mann R-250) to verify the overall quality of the protein separation and to stain the molecular weight 
markers. Gels were prepared for fluorography by the method of Bonner and Laskey (1974), dried on Whatman No. 1 filter paper, placed against preflashed Kodak XAR5 film (Laskey and Mills, 1975), and stored at $-70^{\circ} \mathrm{C}$.

In double-isotope studies, in which intact and regenerating material were co-electrophoresed, gels were first fluorographed to identify the positions of labeled proteins. A tracing of the fluorogram made on acetate was then used as a template to cut labeled proteins out of the gel. Gel segments (average area $=5$ to $10 \mathrm{~mm}^{2}$ ) were hydrated with $60 \mu \mathrm{l}$ of water and prepared for liquid scintillation counting as previously described (Benowitz et al., 1981). The ratio of ${ }^{3} \mathrm{H}$ to ${ }^{14} \mathrm{C}$ for each gel slice, corrected for background and spillover, was normalized by the ratio of the two isotopes initially injected into the regenerating and control eyes. The resulting normalized isotope ratio reflects the extent to which individual protein species are turned on or off during regeneration.

Glial labeling. Control experiments were done to verify that the changes observed during regeneration were associated with proteins transported down the axons of the retinal ganglion cells, and not with glia. Segments of optic nerves regenerating for 30 days were taken from 2 $\mathrm{mm}$ behind the eye up to the chiasm. These were incubated with $\left[{ }^{35} \mathrm{~S}\right]$ methionine for $2 \mathrm{hr}$ at $37^{\circ} \mathrm{C}$ in an aerated medium (Nixon, 1980). Nerves were then homogenized and subjected to subcellular fractionation as described above, and the labeled proteins from the particulate and soluble fractions were analyzed by $2-\mathrm{D}$ gel electrophoresis and fluorography.

Silver staining. In addition to examining the metabolism of proteins in the rapid phase of transport, we also looked at steady-state levels to determine whether the labeling changes that were found reflect a change in turnover rate or a net increase in the amounts of the proteins present. Two-dimensional gels of membranous material derived from tecta receiving either intact or regenerating optic nerves were stained with the reduced silver method of Oakley et al. (1980).

\section{Results}

Rapidly transported proteins in regenerating nerve endings: Studies using $\left[{ }^{35}\right.$ S] methionine labeling. The labeling pattern of rapidly transported proteins is best visualized in the nerve terminals after short survival times, where contamination by more slowly moving components is minimal (Willard et al., 1974; Lorenz and Willard, 1978). Figure 1 shows the 2-D gel pattern of rapidly transported proteins in the membrane fraction of the tectum $16 \mathrm{hr}$ after intraocular labeling with $\left.{ }^{35} \mathrm{~S}\right]$ methionine. In control tecta innervated by intact optic nerves, the principal labeling constitutents are as indicated in Figure $1 A$. On day 19 of regeneration (Fig. $1 B$ ), a general increase is seen in the overall labeling of the rapidly transported proteins. Over and above this general increase, prominent spots appear at $49 \mathrm{~K} 4.6$ and $48 \mathrm{~K} 4.7$ which were not seen in the control case. On day 40 of regeneration (Fig. $1 C$ ) the labeling of these proteins has declined but is still greater than in the control case. Labeling changes for other proteins on the gels are difficult to evaluate due to differences in overall radioactivity among the three cases.

Net accumulation of proteins in reinnervated optic tecta. Silver-stained gels of the tectal plasma membrane fraction are shown in Figure 2. Only a fraction of all the material separated on these gels is associated with retinotectal nerve endings, the majority deriving from tectal interneurons and nonoptic inputs. Nevertheless, differences in the levels of the $48-49 \mathrm{~K}$ acidic proteins still stand out when comparing tecta from day 40 of regeneration (Fig. $2 B$ ) and control tissue (Fig. $2 A$ ). The small amount of these proteins that are visualized in Figure $2 A$ suggests that low levels may normally be associated with optic and/or nonoptic inputs to the tectum.

Double-labeling studies using $\left[{ }^{3} \mathrm{H}\right]$ proline and $\left[{ }^{14} \mathrm{C}\right]$ proline. Quantitative studies using double-isotope comparisons show that relative to the intact state, the labeling increase for the $44-49 \mathrm{~K}$ acidic proteins is over 100 fold on day 19 of regeneration. In the studies shown in Figure 3, proteins were labeled with $\left[{ }^{14} \mathrm{C}\right]$ proline on the regenerating side and $\left[{ }^{3} \mathrm{H}\right]$ proline in the control eye. Sixteen hours later right and left tecta were dissected out, pooled, and co-fractionated, and proteins from the $\mathrm{P}_{2}$ (crude membrane) fraction were separated on 2-D gels. Gels from either day 19 (Fig. $3 A$ ) or day 40 (Fig. $3 C$ ) regenerating material show extremely high labeling of the $44-49 \mathrm{~K}$ acidic proteins with proline relative to methionine (cf. Fig. $1 B$ ), to the extent that with proline the proteins become the dominant labeled spots on the gels. One or more heavily labeled proteins appear at $44 \mathrm{~K}$ 4.5 to 4.6 , which had not even been visualized using methionine. Figure $3, B$ and $D$, shows the ${ }^{14} \mathrm{C} /{ }^{3} \mathrm{H}$ ratios for proteins on these gels normalized by the ratio of the two isotopes initially injected. Relative to the intact state, labeling in the group of proteins between $44 \mathrm{~K}$ and $49 \mathrm{~K}$, isoelectric point (pI) 4.6 to 4.9 , increased 130 -fold on day 19 and 30 -fold on day 40 . Proteins at $120 \mathrm{~K} 5.4$ and $110 \mathrm{~K} 5.4$ to 5.6, also showed large increases relative to the intact state, as did components at $30 \mathrm{~K}$ and near the dye front.

Soluble proteins associated with the rapid phase of transport. Increased labeling of the $44-49 \mathrm{~K}$ acidic proteins during regeneration also appears in the soluble fraction of the tectum $16 \mathrm{hr}$ after intraocular labeling. Figure $4, A$ and $B$, compares the $\left[{ }^{35}\right.$ S]methionine incorporation profiles for soluble proteins in tecta contralateral to intact (Fig. $4 A$ ) and regenerating (Fig. $4 B$ ) optic nerves. In the 19-day regenerating case, labeled components appear at $48 \mathrm{~K}, 4.8$ and $49 \mathrm{~K} 4.7$, which are not visible in the controls. Figure $4 C$ shows the fluorogram of soluble tectal proteins for a double-labeling study in which $\left[{ }^{14} \mathrm{C}\right]$ proline was injected on the regenerating side and $\left[{ }^{3} \mathrm{H}\right]$ proline was injected in the control eye. The normalized ${ }^{14} \mathrm{C} /{ }^{3} \mathrm{H}$ ratios, illustrated in Figure $4 D$, again show the principal labeling changes on the gel to be for the $44-49 \mathrm{~K}$ acidic proteins. Other labeling changes are seen for several high molecular weight components as indicated in the figure; most of these other proteins are not seen in the methionine-labeled material, whereas conversely, many proteins that are prominently labeled with methionine do not incorporate appreciable proline. With either isotope, a cluster of spots between 29,000 and 40,000 daltons labels heavily. In another experiment (gel not shown) we have found that, even in parts of the brain which do not receive retinal input (e.g., the vagal and facial lobes of the medulla), this group of proteins 
Benowitz and Lewis
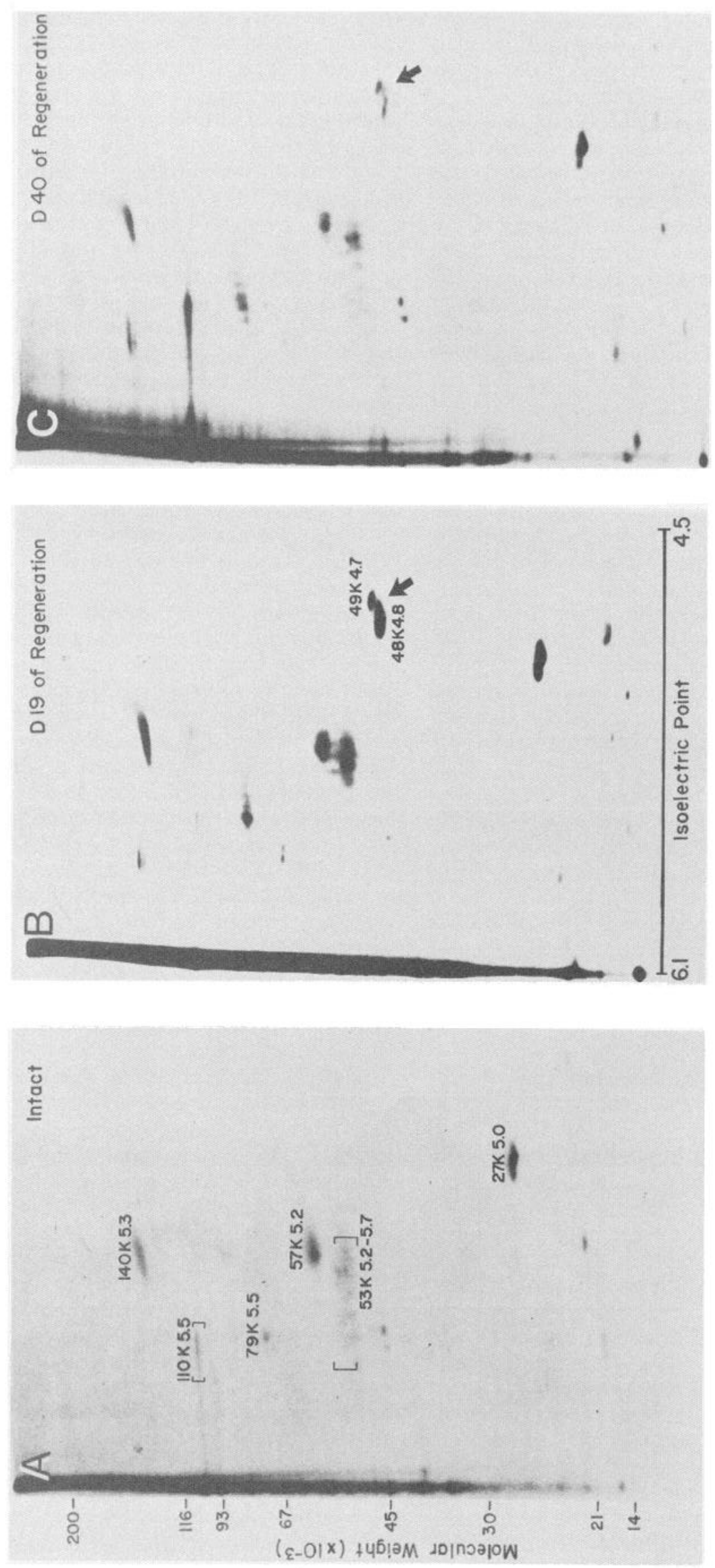

Vol. 3, No. 11, Nov. 1983

.气 莺 范

范

需

氜

$4 \pm \frac{1}{3}$

ष: 苋

ปิ กิ

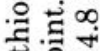

بx

至.

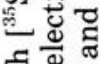

恶罗

우웅

ฮี สิ

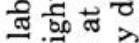

푸 0

ग के के

\%

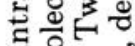

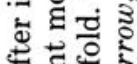

๘

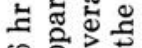

능

동

总灾

这.

ธัँ

है क्ष क

돈

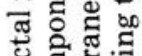

घ․ำ

ฐ

옹쥬

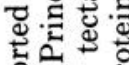

는

क ग्र

焉河

की

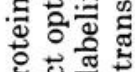

品

넝. 픙흐

क 훈

ส $5 \equiv$

ํํㅇ

कृ 둥

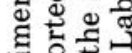

कृ क०

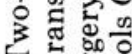

들

ऽ

공원.

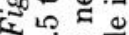

뭉 

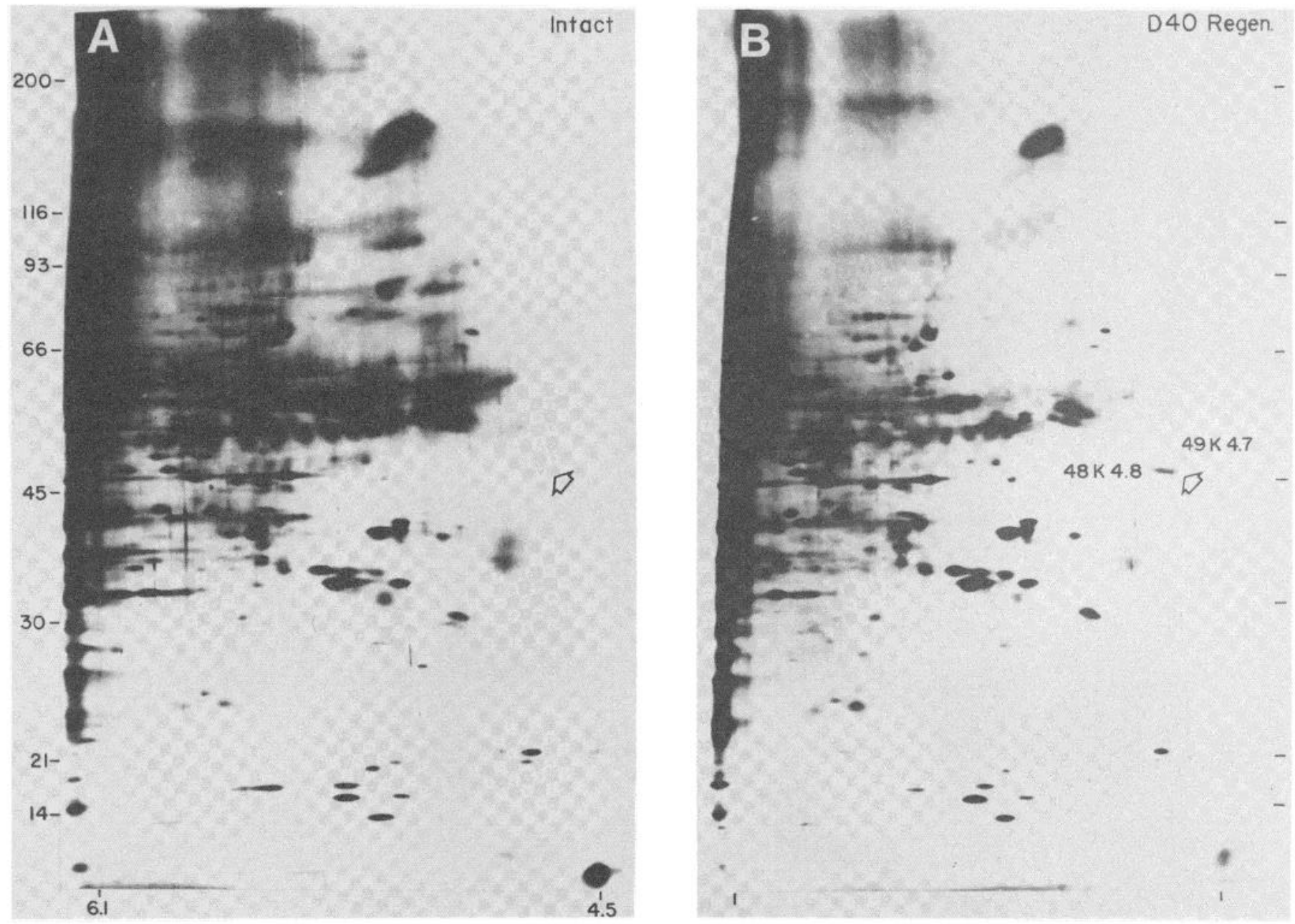

Figure 2. Two-dimensional gels of the tectal plasma membrane fraction stained using the reduced silver method of Oakley et al. (1980). A, Gel from tecta receiving input from intact optic nerves shows faint spots at $49 \mathrm{~K} 4.7$ and $48 \mathrm{~K} 4.8$ (arrow). $B$, Increased amounts of these proteins appear in a gel from tecta innervated by regenerating optic nerves.

shows an appreciable degree of labeling $16 \mathrm{hr}$ after radioactive precursors had been injected in the eye. This indicates that the $29-40 \mathrm{~K}$ proteins are not axonally transported but probably become labeled systemically. Further evidence of these components not being axonally transported is their absence on gels of the optic nerve soluble fraction. The $29-40 \mathrm{~K}$ proteins most likely correspond to $\beta$ - and $\gamma$-ependymin, the most abundant constituents of goldfish brain extracellular fluid, which are secreted from a large population of periependymal astrocytes (Benowitz and Shashoua, 1977; Shashoua, 1979; Majocha et al., 1983).

An isotope reversal experiment, in which $\left[{ }^{3} \mathrm{H}\right]$ proline was injected on the regenerating side and $\left[{ }^{14} \mathrm{C}\right]$ proline was injected in the control eye 40 days after surgery, is shown in Figure 4, $E$ and $F$. Although the overall labeling increase during regeneration was small in this instance, the greatest specific change was still for the $44-49 \mathrm{~K}$ acidic proteins. Similarly prepared isotope reversal material from day 19 of regeneration likewise showed the $44-49 \mathrm{~K}$ acidic proteins to have the greatest relative change during regeneration (not shown).
Proteins in transit down the optic nerve. Particulate proteins labeled in the optic nerve $16 \mathrm{hr}$ after intraocular injections of precursors are shown in Figure 5 . The labeling profiles of these gels are considerably more complex than in Figures 2 and 3, since components moving as slowly as $2 \mathrm{~mm} /$ day will also be present, particularly in proximal portions of the optic nerve. Nevertheless, changes in the $44-49 \mathrm{~K}$ acidic proteins are still apparent in this material (arrow, Fig. $5 B$ ). Other differences between intact and regenerating nerves which appeared in at least three of four replicate experiments are noted in Figure $5 B$. The proteins indicated at $51-55 \mathrm{~K}$ 5.4 and at $45 \mathrm{~K} 5.6$ (Fig. $5 A$ ) probably correspond, respectively, to tubulin and actin (Strocchi et al., 1981; Heacock and Agranoff, 1982).

Doubly labeled material in transit down intact and regenerating optic nerves is shown in Figure $5 C$, and once again the relative labeling of proteins with proline and methionine is quite different. The $44-49 \mathrm{~K}$ acidic proteins are the heaviest labeled components in the proline incorporation material and, as shown by the normalized ${ }^{3} \mathrm{H} /{ }^{14} \mathrm{C}$ ratios in Figure $5 D$, they once more 


\section{DAY 19}
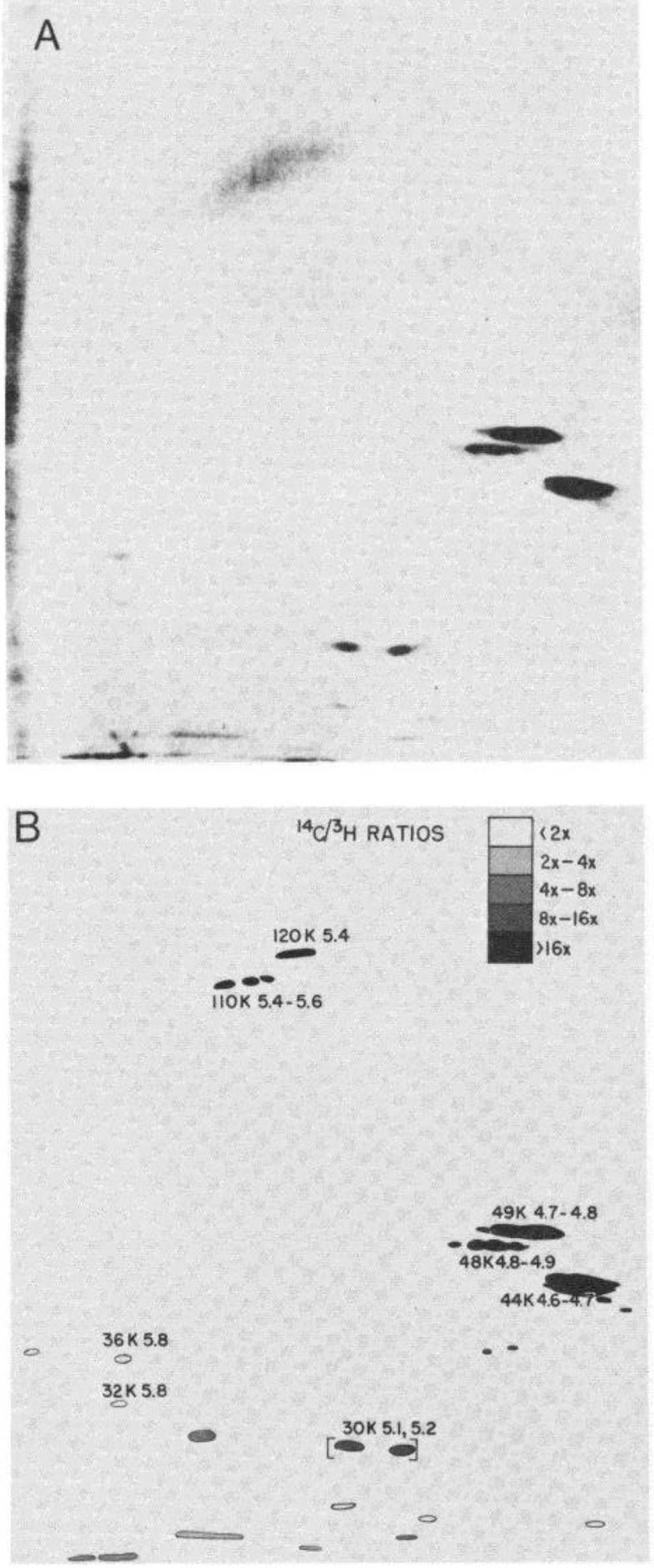
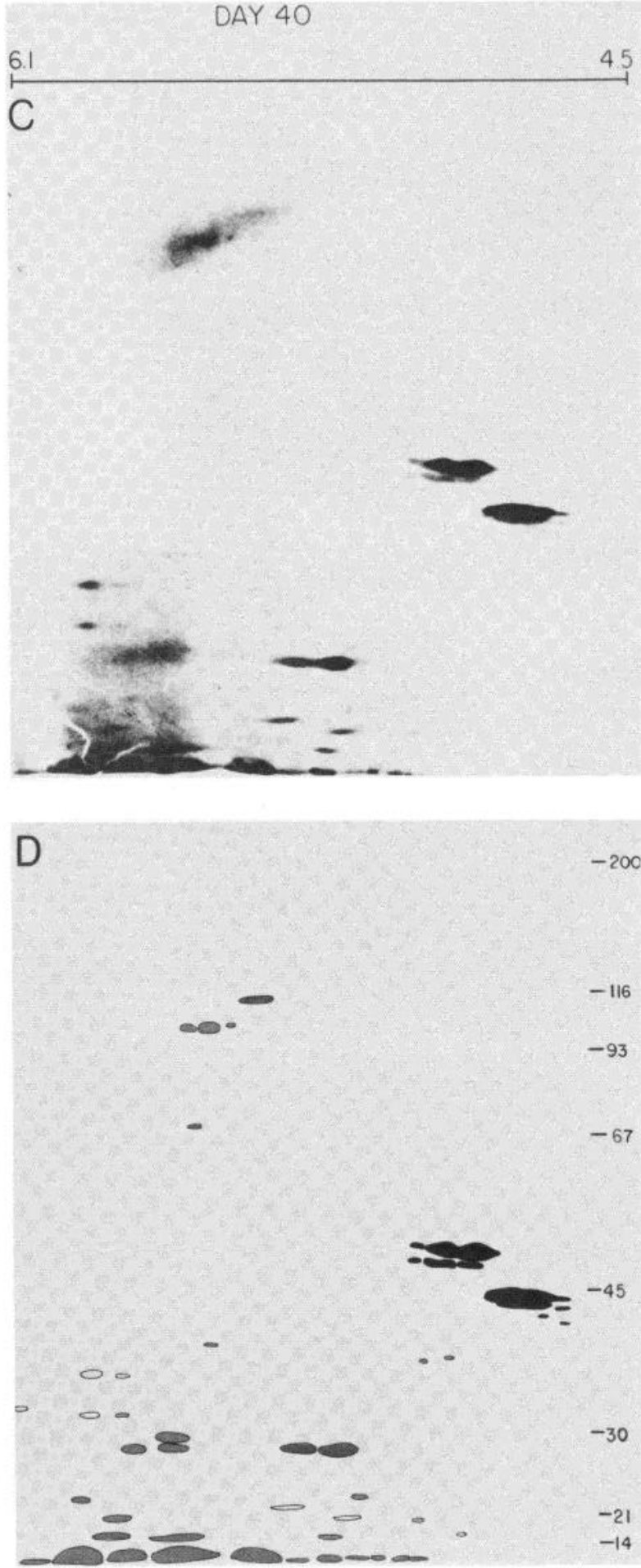

Figure 3. Specific protein changes during regeneration quantified using double-isotope labeling. Sixteen hours after the regenerating and intact eyes were labeled, respectively, with $\left[{ }^{14} \mathrm{C}\right]$ - and $\left[{ }^{3} \mathrm{H}\right]$ proline, right and left tecta were pooled and copurified to a $\mathrm{P}_{2}$ fraction, and the proteins were co-separated on 2-D gels. $A$ and $C$, Fluorograms of doubly labeled proteins on days 19 and 40 of regeneration. Acidic proteins between $44 \mathrm{~K}$ and $49 \mathrm{~K}$ are seen to incorporate much more proline than methionine. $B$ and $D$, Normalized isotope ratios for individual proteins illustrated using the scale in $B$. The actual increase measured for the 44-49K acidic proteins was 130 -fold on day 19 and 30 -fold on day 40 .

show large specific labeling increases on day 19 of regeneration. A series of more acidic, lower molecular weight spots are seen trailing away from the $44 \mathrm{~K} 4.6$ protein, perhaps reflecting breakdown products. Other increases associated with regeneration appear at $160 \mathrm{~K} 5.2$ and 145K 5.4. Many of the other spots which are prominent in Figure $5, A$ and $B$ did not incorporate enough proline to be identified for counting. 

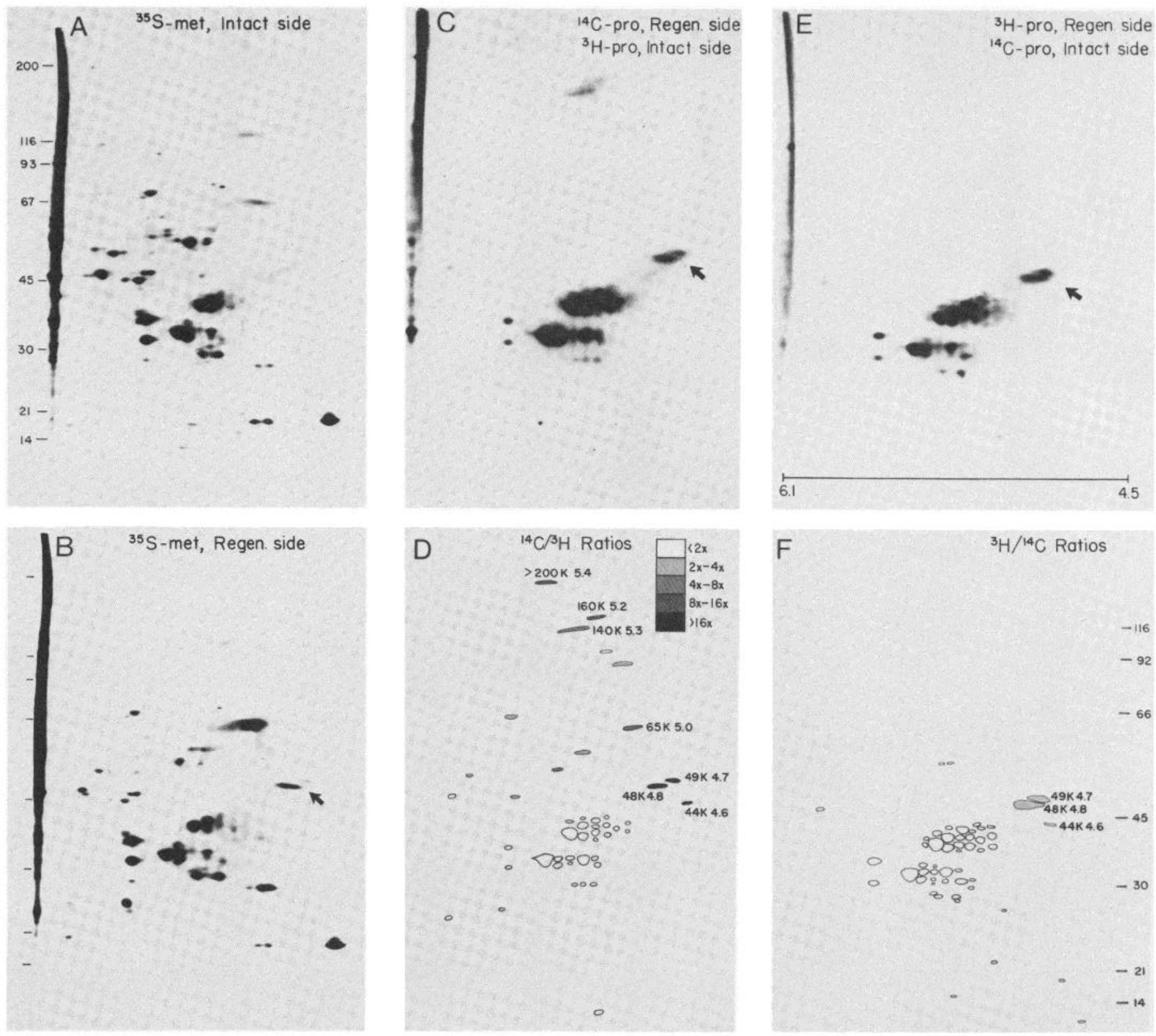

Figure 4. Protein labeling patterns in the tectal cytosol fraction $16 \mathrm{hr}$ after intraocular labeling. $A$ and $B$, Comparison of proteins labeled with $\left.{ }^{35} \mathrm{~S}\right]$ methionine (met) in tecta receiving intact and regenerating optic nerves. On day 19 of regeneration $(B)$ a heavily labeled spot at $48 \mathrm{~K} 4.8$ and a light one at $49 \mathrm{~K} 7.7$ are visible (arrow) which are not detected in normal material. $C$ and $D$, Fluorogram and normalized isotope ratios for soluble tectal proteins labeled with $\left[{ }^{3} \mathrm{H}\right]-$ and $\left[{ }^{14} \mathrm{C}\right]$ proline (pro; day 19 of regeneration). Large specific labeling increases are seen for 44-49K acidic proteins. Lesser changes for other species are also noted. $E$ and $F$, Fluorogram and normalized labeling ratios for an isotope reversal experiment $\left(\left[{ }^{3} \mathrm{H}\right]\right.$ proline injected on the regenerating side). The overall labeling increase during regeneration was small in this experiment, but the $44-49 \mathrm{~K}$ acidic proteins still showed the largest relative increase.

Analysis of the soluble proteins in the optic nerve 16 $\mathrm{hr}$ after intraocular labeling gave results similar to those found in the particulate fraction (not shown). In methionine-labeled material, an acidic protein at $48 \mathrm{~K}$ was faintly visible in regenerating nerves and absent in the controls. In doubly labeled material, the $44-49 \mathrm{~K}$ acidic proteins stood out as the most prominently labeled spots on the gels and once again showed the greatest changes during regeneration of any protein.

The analyses of soluble plus total particulate compo- nents transported down the nerve demonstrate that the increased labeling of the $44-49 \mathrm{~K}$ acidic proteins remains prominent when the totality of material in the retinotectal pathway is analyzed. Thus, the increased labeling of these proteins is not an artifact of a differential distribution of similar components in regenerating and intact nerves during subcellular fractionation.

Proteins of the glial sheath cells. To verify that the 44$49 \mathrm{~K}$ acid proteins are transported in axons, rather than being glial constituents which might change during re- 

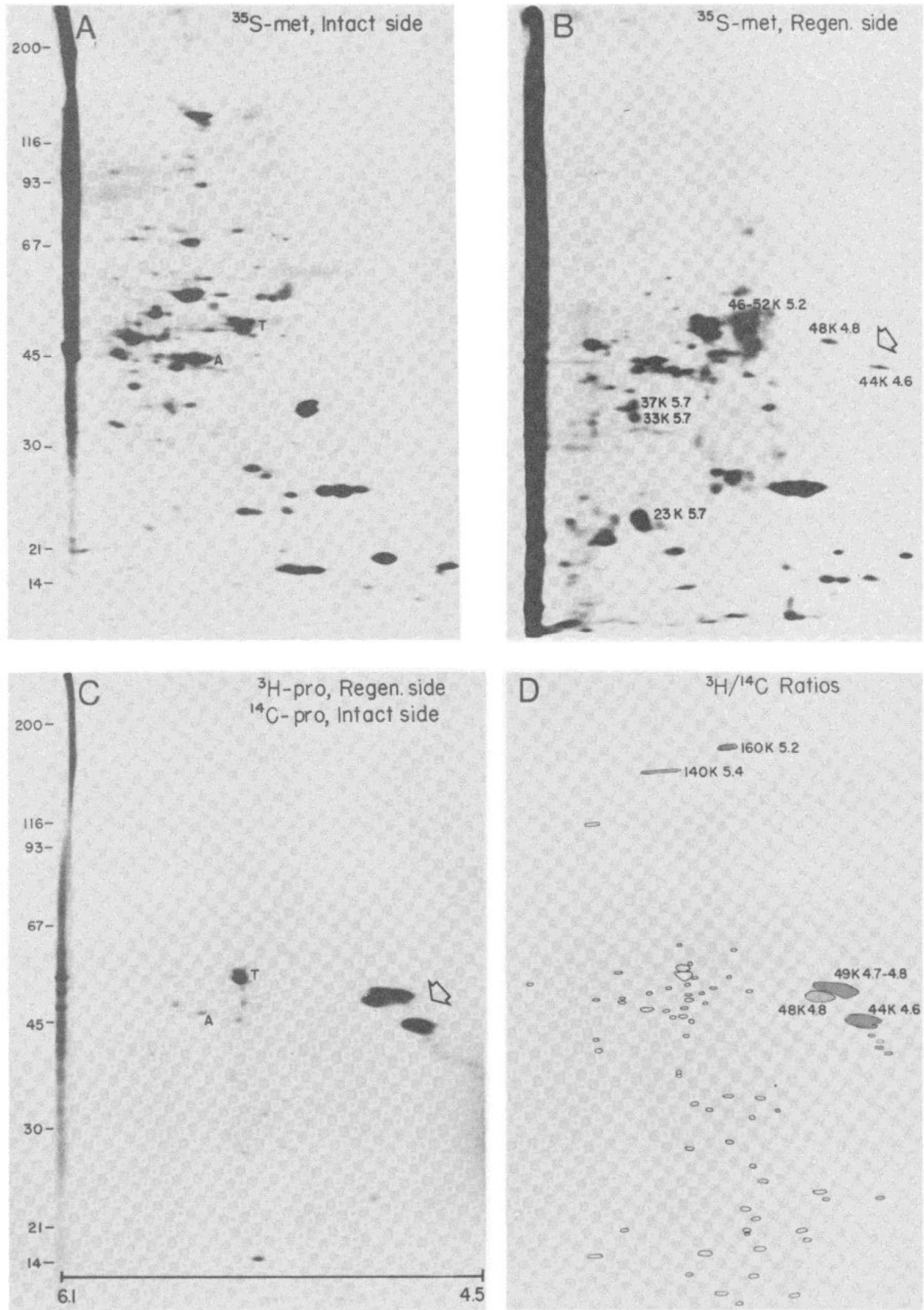

Figure 5. Proteins in the particulate fraction of the optic nerve $16 \mathrm{hr}$ after intraocular labeling with $\left[{ }^{35} \mathrm{~S}\right] \mathrm{methionine}$. Two spots appear at $48 \mathrm{~K} 4.8$ and $44 \mathrm{~K} 4.6$ on day 19 of regeneration (arrow, $B$ ) which are absent in intact nerves $(A)$. Reproducible increases in other proteins during regeneration are also noted. $C$ and $D$, Fluorogram and normalized isotope ratios for doublelabeled proteins in transit down intact and regenerating optic nerves (day 19). The acidic proteins between $44 \mathrm{~K}$ and $49 \mathrm{~K}$ (arrow) are again seen to label very heavily with proline and show the greatest overall increase during regeneration. 

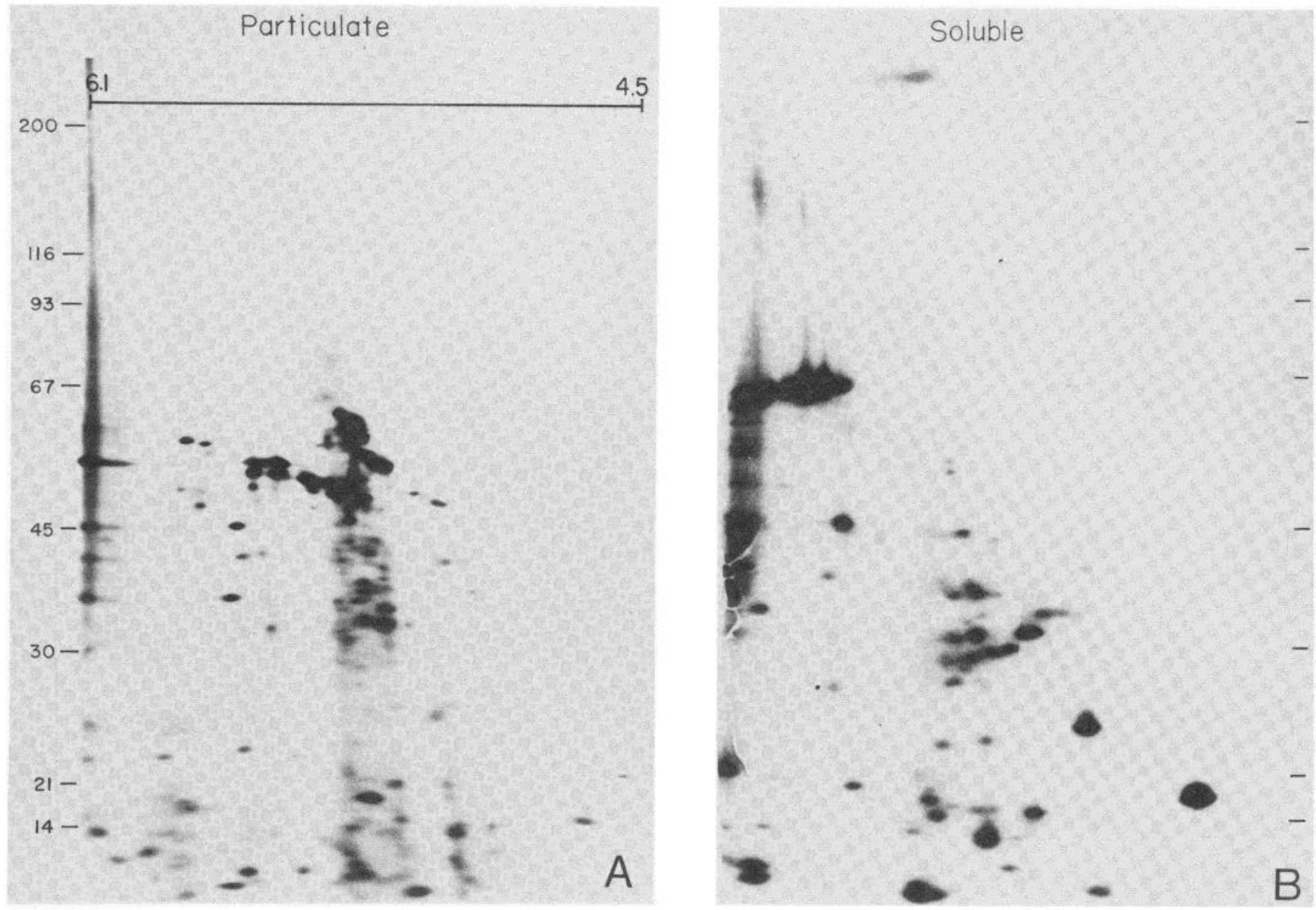

Figure 6. Proteins synthesized in vitro by the Schwann cells of the optic nerve during regeneration. The $44-49 \mathrm{~K}$ acidic proteins are not detected in either particulate $(A)$ or soluble $(B)$ fractions.

generation, segments of regenerating optic nerves (day 30 postsurgery) were labeled in vitro. The resulting $\left[{ }^{35} \mathrm{~S}\right]$ methionine incorporation profiles, shown in Figure 6, show no evidence of the $44-49 \mathrm{~K}$ acidic proteins in either the particulate (Fig. $6 A$ ) or soluble (Fig. $6 B$ ) fractions of glia.

Presence of the 44-49K proteins in intact nerves. Since the spots from double-labeling experiments are cut out of gels and counted, it is possible to quantify the amounts of the acidic $44-49 \mathrm{~K}$ proteins in both intact and regenerating material as a fraction of the total radioactivity on the gels. In intact nerves, these proteins accounted for an average of $6 \%$ of the total proline incorporated into all species resolved on the gels. In view of this figure, their low level in silver-stained gels of intact nerve terminal membranes (Fig. $2 A$ ) is not surprising, particularly since the proteins could derive from optic as well as nonoptic terminals in the tectum. Experiments using $\left[{ }^{35} \mathrm{~S}\right]$ methionine as a precursor also occasionally showed faint labeling of these proteins in some of our intact material, although not at a level which photographed well.

\section{Discussion}

These results show that during regeneration of the goldfish optic nerve there is a dramatic increase in the labeling of a group of rapidly transported proteins having $M_{\mathrm{r}}$ between 44,000 and 49,000 and isoelectric points between 4.6 and 4.9. These proteins are present in both the membrane-bound and soluble fractions of material transported from the retinal ganglion cells to the nerve terminals in the tectum. They are normally present in low amount, but during regeneration their labeling increases up to 100 -fold in some instances. These changes reflect not only an increase in synthesis but also an increase in the total amount of the proteins present, as visualized on silver-stained 2-D gels of the tectal membrane fraction. The acidic $44-49 \mathrm{~K}$ proteins are rich in proline relative to methionine, and when radiolabeled proline is used as a metabolic precursor, the proteins become the most heavily labeled spots on our gels during regeneration.

Studies using double-labeling and 1-D gel separation methods (Benowitz et al., 1981) previously reported a labeling increase at 44,000 daltons to be among the principal changes in the complement of rapidly transported proteins appearing in the optic nerve during regeneration. However, the magnitude of this change had been vastly underestimated due to masking by other labeled components in the nerve which have similar molecular weights but whose metabolism is relatively unchanged during regeneration (e.g., actin, $M_{\mathrm{r}}=45,000$; 
see Fig. 5). A subsequent study showed the $44 \mathrm{~K}$ protein(s) to become associated with a nerve terminal membrane fraction of the optic tectum (Benowitz and Padda, 1981), where the labeling change during regeneration was measured as being larger than had been found in the optic nerve. However, using 2-D scparation, the magnitude of this change is seen to be far greater still. Although intergroup variations were found in the present study, both for the overall protein labeling change during regeneration (Heacock and Agranoff, 1982) and for the specific increases at $44-49 \mathrm{~K}$, the relative change for these components was always the greatest of any species resolved on our gels. As in the previous study, these increases were larger 19 days after surgery than on day 40; beyond day 60 or so, most of the changes in rapidly transported protein metabolism disappear (Benowitz et al., 1981). Labeling increases of a lesser magnitude were also found in this study for rapidly transported species at $160 \mathrm{~K} 5.2$, $140 \mathrm{~K} 5.3$ to 5.4 , and $110-120 \mathrm{~K} 5.4$, in agreement with observations made in the previous 1-D analysis. Increases in more slowly moving components were noted

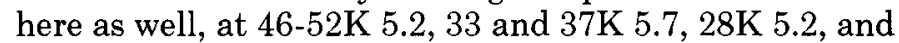
$23 \mathrm{~K} 5.7$, although these changes were not examined systematically.

Increased labeling of a rapidly transported $45 \mathrm{~K}$ protein has recently been confirmed in the regenerating goldfish optic nerve using 1-D gels (Heacock and Agranoff, 1982), and in the regenerating toad optic system, Skene and Willard (1981a) have shown increases in an acidic 43K protein ( $45 \mathrm{~K}$ by our molecular weight calibration) to be among the principal changes occurring in the rapid phase of axonal transport in studies that used 2-D gels and $\left[{ }^{35} \mathrm{~S}\right]$ methionine as a precursor. Increased labeling of a similar protein is seen during the development of the rabbit visual system and in the regenerating rabbit sciatic nerve (Skene and Willard, 1981b). Regeneration in the toad visual system has also been associated with increased labeling of rapidly transported proteins at $50 \mathrm{~K}$ and $24 \mathrm{~K}$. The present study presumably did not visualize these latter two because the $50 \mathrm{~K}$ component is a basic protein, the isoelectric point of which is outside the range of the gel system used here, whereas the $24 \mathrm{~K}$ species has a short half-life and requires urea in the second-dimension gel for electrophoresis (Skene and Willard, 1981a, c).

The interrelationship among the various labeled spots between 44 and $49 \mathrm{~K}$, pI 4.6 to 4.9 , cannot be determined from the present data. At least three different molecular weight classes are visible in many of our gels (Figs. 3 and 5) and in some cases the spot at $48 \mathrm{~K}$ appears to be resolved into several components (Figs. $1 C$ and $3 B$ ). Some similarity among all of these seems likely in terms of their being turned on in concert during regeneration and in terms of their all having a high proportion of proline relative to methionine. Whether the various spots have some precursor-product relationship, are distinct gene products, or represent differing states of post-translational modification (e.g., glycosylation or phosphorylation) from a common parent polypeptide is as yet unknown; cell-free protein synthesis studies may prove helpful in clarifying this question.

Proteins in the rapid phase of axonal transport, by virtue of their association with smooth endoplasmic reticulum, synaptic vesicles, and plasma membrane, have been presumed to participate in such phenomena as membrane renewal, neurosecretion, ion transport, transmitter metabolism and release, intercellular recognition, and trophic interactions (Bennett ct al., 1973; Droz et al., 1975; Lorenz and Willard, 1978; Hammerschlag and Stone, 1982). Whether the $44-49 \mathrm{~K}$ acidic proteins participate in any of these particular events is, of course, outside the scope of this study. Temporally, the proteins seem to be most abundant during early stages of axonal outgrowth, before the time of synaptogenesis (Murray, 1976,1982 ). We have recently found that their abundance at this stage occurs regardless of whether the developing nerve is allowed to contact the optic tectum, although interactions with the tectum do cause a selective turning on of other rapidly transported species (M. G. Yoon, L. I. Benowitz, and F. A. Baker, manuscript in preparation). Perhaps the appearance of the $44-49 \mathrm{~K}$ acidic proteins in regenerating nerves is endogenously controlled in the somata after deafferentation, possibly by the removal of a normal retrogradely transported regulatory signal; alternatively, the increase may be regulated by a humoral factor accessible to the outgrowing neurites before they contact their target cells. Assuming that among the 44-49K group of acidic proteins are components similar to the $43 \mathrm{~K}$ acidic protein, GAP-43, identified by Skene and Willard (1981a, b), it would seem that changes in the biosynthesis and/or transport of these polypeptides may be an evolutionarily conserved feature common to many instances of vertebrate neural development.

\section{References}

Attardi, D. G., and R. W. Sperry (1963) Preferential selection of central pathways hy regenerating optic fibers. Fxp. Neurol. 7: 46-64.

Bennett, G., L. DiGiamberadino, H. L. Koenig, and B. Droz (1973) Axonal migration of protein and glycoprotein to nerve endings. II. Radioautographic analysis of the renewal of glycoproteins in nerve endings of chicken ciliary ganglion after intracerebral injection of $\left[{ }^{3} \mathrm{H}\right]$ fucose and $\left[{ }^{3} \mathrm{H}\right]$ glucosamine. Brain Res. 60: 129-146.

Benowitz, L. I., and K. Padda (1981) Molecular changes in regenerating retinotectal nerve terminals. Soc. Neurosci. Abstr. 7: 678 .

Benowitz, L. I., and V. E. Shashoua (1977) Localization of a brain protein metabolically associated with behavioral plasticity in the goldfish. Brain Res. 136: 227-242.

Benowitz, L. I., V. E. Shashoua, and M. G. Yoon (1981) Specific changes in rapidly transported proteins during regeneration of the goldfish optic nerve. J. Neurosci. 1: 300-307.

Benowitz, L. I., M. G. Yoon, and E. R. Lewis (1983) Transported proteins in the regenerating optic nerve: Regulation by interactions with the optic tectum. Science, in press.

Bonner, W. M., and R. A. Laskey (1974) A film detection method for tritium-labeled proteins and nucleic acids in polyacrylamide gels. Eur. J. Biochem. 46: 83-88.

Droz, B., D. Rambourg, and H. L. Koenig (1975) The smooth endoplasmic reticulum: Structure and role in the renewal of axonal membrane and synaptic vesicles by fast axonal transport. Brain Res. 93: 1-13.

Giulian, D., H. Des Ruisseaux, and D. Cowburn (1980) Biosynthesis and intra-axonal transport of proteins during neuronal regeneration. J. Biol. Chem. 255: 6494-6501. 
Grafstein, R., and D. S. Forman (1980) Intracellular transport in neurons. Physiol. Rev. 60: 1167-1283.

Grafstein, B., and M. Murray (1969) Transport of protein in goldfish optic nerve during regeneration. Exp. Neurol. 25: 494-508.

Grafstein, B., D. S. Forman, and B. S. McEwen (1972) Effects of temperature on axonal transport and turnover of protein in the goldfish visual system. Exp. Neurol. 34: 158-170.

Hammerschlag, R., and G. C. Stone (1982) Membrane delivery by fast axonal transport. Trends Neurosci. 5: 12-15.

Heacock, A. M., and B. W. Agranoff (1982) Protein synthesis and transport in the regenerating goldfish visual system. Neurochem. Res. 7: 771-788.

Jacobson, M., and R. M. Gaze (1965) Selection of appropriate tectal connections by regenerating optic nerve fibers in adult goldfish. Exp. Neurol. 13: 418-430.

Laemmli, U. K. (1970) Cleavage of structural proteins during the assembly of the head of bacteriophage T4. Nature 227: 680-685.

Laskey, R. A., and A. D. Mills (1975) Quantitative film detection of ${ }^{3} \mathrm{H}$ and ${ }^{14} \mathrm{C}$ in polyacrylamide gels by fluorography. Eur. J. Biochem. 56: 335-341.

Lorenz, T., and M. Willard (1978) Subcellular fractionation of intra-axonally transported polypeptides in the rabbit visual system. Proc. Natl. Acad. Sci. U. S. A. 75: 505-509.

Majocha, R. E., R. Schmidt, and V. E. Shashoua (1982) Cultures of zona ependyma cells of goldfish brain: An immunological study of the synthesis and release of ependymins. J. Neurosci. Res. 8: 331-342.

McQuarrie, I. G., and B. Grafstein (1982) Protein synthesis and fast axonal transport in regenerating goldfish retinal ganglion cells. Brain Res. 235: 213-223.

Murray, M. (1976) Regeneration of retinal axons into the goldfish optic tectum. J. Comp. Neurol. 168: 175-195.

Murray, M. (1982) A quantitative study of regenerative sprouting by optic axons in goldfish. J. Comp. Neurol. 209: 352362.
Nixon, R. A. (1980) Protein degradation in the mouse visual system. I. Degradation of axonally transported and retinal proteins. Brain Res. 200: 69-83.

Oakley, B. R., D. R. Kirsch, and N. R. Morris (1980) A simplified ultrasensitive silver stain for detecting proteins in polyacrylamide gels. Anal. Biochem. 105: 361-363.

O'Farrell, P. H. (1975) High resolution two-dimensional electrophoresis of proteins. J. Biol. Chem. 250: 4007-4021.

Quitschke, W., A. Fruncis, and N. Schechter (1980) Electrophoretic analysis of specific proteins in the regenerating goldfish retinotectal pathway. Brain Res. 201: 347-360.

Shashoua, V. E. (1979) Brain metabolism and the acquisition of new behaviors. III. Evidence for secretion of two proteins into the brain extracellular fluid after training. Brain Res. 166: $349-358$.

Skene, J. H. P., and M. Willard (1981a) Changes in axonally transported proteins during axon regeneration in toad retinal ganglion cells. J. Cell Biol. 89: 86-95.

Skene, J. H. P., and M. Willard (1981b) Axonally transported proteins associated with axon growth in rabbit central and peripheral nervous system. J. Cell Biol. 89: 96-103.

Skene, J. H. P., and M. Willard (1981c) Characteristics of growth-associated polypeptides in regenerating toad retinal ganglion cell axons. J. Neurosci. 1: 419-426.

Sperry, R. W. (1948) Patterning of central synapses in regeneration of the optic nerve in teleosts. Physiol. Zool. 21: 351361.

Strocchi, P., B. A. Brown, J. D. Young, J. A. Bonventre, and J. M. Gilbert (1981) The characterization of tubulin in CNS membrane fractions. J. Neurochem. 37: 1295-1307.

Whittaker, V. P., and P. Greengard (1971) The isolation of synaptosomes from the brain of a teleost fish, Centriopristes striatus. J. Neurochem. 18: 173-176.

Willard, M., W. M. Cowan, and R. Vagelos (1974) The polypeptide composition of intra-axonally transported proteins: Evidence for four transport velocities. Proc. Natl. Acad. Sci. U. S. A. 71: 2183-2187. 